\title{
Respiratory and metabolic acidosis correction with the ADVanced Organ Support system
}

Aritz Perez Ruiz de Garibay ${ }^{1 *}$, John A. Kellum², Johannes Honigschnabel ${ }^{3}$ and Bernhard Kreymann ${ }^{1}$

\author{
* Correspondence: aritz.perez@ \\ advitos.com \\ ${ }^{1}$ ADVITOS GmbH, \\ Agnes-Pockels-Bogen 1, 80992 \\ Munich, Germany \\ Full list of author information is \\ available at the end of the article
}

\begin{abstract}
Background: The lung, the kidney, and the liver are major regulators of acid-base balance. Acidosis due to the dysfunction of one or more organs can increase mortality, especially in critically ill patients. Supporting compensation by increasing ventilation or infusing bicarbonate is often ineffective. Therefore, direct removal of acid may represent a novel therapeutic approach. This can be achieved with the ADVanced Organ Support (ADVOS) system, an enhanced renal support therapy based on albumin dialysis. Here, we demonstrate proof of concept for this technology.
\end{abstract}

Methods: An ex vivo model of either hypercapnic (i.e., continuous $\mathrm{CO}_{2}$ supply) or lactic acidosis (i.e., lactic acid infusion) using porcine blood was subjected to hemodialysis with ADVOS. A variety of operational parameters including blood and dialysate flows, different dialysate $\mathrm{pH}$ settings, and acid and base concentrate compositions were tested. Comparisons with standard continuous veno-venous hemofiltration $(\mathrm{CWH})$ using high bicarbonate substitution fluid and continuous veno-venous hemodialysis (CWHD) were also performed.

Results: Sixty-one milliliters per minute $(2.7 \mathrm{mmol} / \mathrm{min})$ of $\mathrm{CO}_{2}$ was removed using a blood flow of $400 \mathrm{ml} / \mathrm{min}$ and a dialysate $\mathrm{pH}$ of 10 without altering blood $\mathrm{pCO}_{2}$ and $\mathrm{HCO}_{3}{ }^{-}$(36 mmHg and $20 \mathrm{mmol} / \mathrm{l}$, respectively). Up to $142 \mathrm{ml} / \mathrm{min}(6.3 \mathrm{mmol} / \mathrm{min}$ ) of $\mathrm{CO}_{2}$ was eliminated if elevated $\mathrm{pCO}_{2}(117 \mathrm{mmHg})$ and $\mathrm{HCO}_{3}{ }^{-}(63 \mathrm{mmol} / \mathrm{l})$ were allowed. During continuous lactic acid infusion, an acid load of up to $3 \mathrm{mmol} / \mathrm{min}$ was compensated. When acidosis was triggered, ADVOS multi normalized $\mathrm{pH}$ and bicarbonate levels within $1 \mathrm{~h}$, while neither $\mathrm{CWH}$ nor CWHD could. The major determinants to correct blood $\mathrm{pH}$ were blood flow, dialysate composition, and initial acid-base status.

Conclusions: In conclusion, ADVOS was able to remove more than $50 \%$ of the amount of $\mathrm{CO}_{2}$ typically produced by an adult human. Blood $\mathrm{pH}$ was maintained stable within the physiological range through compensation of a metabolic acid load by albumin dialysate. These in vitro results will require confirmation in patients.

Keywords: Multiple organ failure, Respiratory hemodialysis, Extracorporeal carbon dioxide removal, Respiratory acidosis, Metabolic acidosis, Lactic acidosis, ECCO2R, Albumin dialysis, Extracorporeal organ support

\section{Introduction}

Lung, kidney, and hepatic dysfunction are common in the critically ill, and acid-base regulation is frequently compromised in these patients. Acidosis is commonly

(c) The Author(s). 2019 Open Access This article is distributed under the terms of the Creative Commons Attribution 4.0 International License (http://creativecommons.org/licenses/by/4.0/), which permits unrestricted use, distribution, and reproduction in any medium, provided you give appropriate credit to the original author(s) and the source, provide a link to the Creative Commons license, and indicate if changes were made. 
associated with high mortality rates in critically ill and injured patients. Recently, a strong correlation was found between hypercapnic acidosis and increased hospital mortality in mechanically ventilated patients, compared to compensated hypercapnia or normocapnia [1]. Indeed, a delayed $\mathrm{pH}$ normalization is associated with increased mortality in the intensive care unit (ICU), reaching $57 \%$ in cases of severe metabolic or mixed acidemia [2]. If accompanied by hyperlactatemia, these values could go above $80 \%[3,4]$.

While acidosis is well tolerated in healthy humans, acidosis leads to a myriad of physiologic effects that can be deleterious and thus contribute to morbidity and mortality in patients [5]. In fact, an interaction exists between acidosis and inflammation, which is specifically relevant in critically ill patients [6,7]. Acidosis can impair several immune response mechanisms, including lymphocyte cytotoxicity, complement activation, or antibody binding to leukocytes [8]. Since some of these findings have been already reported in patients [7], acid-base imbalances should be considered in the context of a host response to an aggression, and not as an isolated insult. Moreover, $\mathrm{pH}$ might also influence normal physiology, among others, modulating oxygen affinity to hemoglobin $[9,10]$, promoting vasoconstriction in the lungs [11], altering potassium and calcium levels, reducing glomerular filtration rate [12], reducing intestinal mobility [13], impairing coagulation [14], or depressing myocardial contractility [9].

The ADVanced Organ Support (ADVOS) system (ADVITOS GmbH, Munich, Germany-previously, Hepa Wash $\mathrm{GmbH}$ ) is an albumin-based hemodialysis device initially designed to support the liver and kidney of ICU patients. As a hemodialysis system, it removes water-soluble substances, while the albumin dialysate allows to remove protein-bound toxins too [15-17]. The ADVOS system consists of three circuits: an extracorporeal blood, a dialysate, and an ADVOS multi circuit with an acidic and an alkaline path (Fig. 1). Briefly, the dialysate's albumin binds protein-bound substances that diffuse from blood into the dialysate through a semi-permeable membrane in the extracorporeal circuit. Differently to conventional single pass albumin dialysis (SPAD), in the ADVOS system, the dialysate is not systematically discarded and recirculates

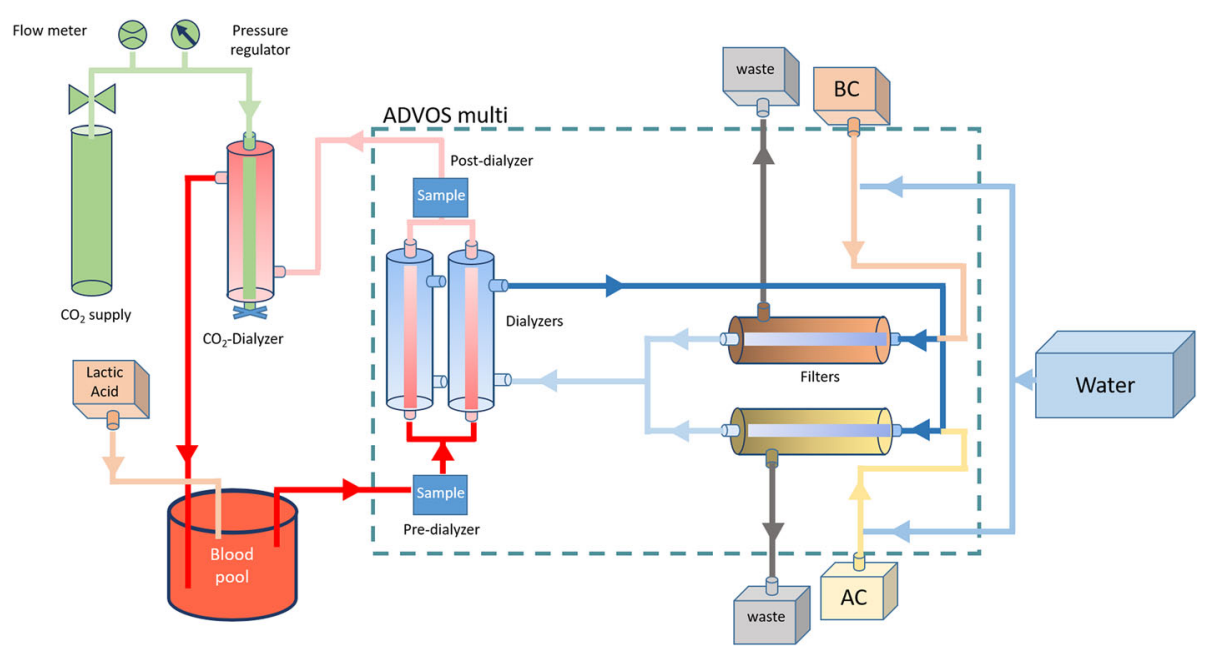

Fig. 1 Schematic representation of ADVOS multi device with a continuous $\mathrm{CO}_{2}$ supply. Lactic acid was supplied in blood only for experimental settings 2 and 4 (see Table 1 for more details) 
then through the dialysate circuit into the ADVOS multi circuit. There, dialysate albumin is recycled by systematically modifying the tertiary structure of albumin through temperature and $\mathrm{pH}$ changes. This facilitates the release of toxins from albumin (cationic-e.g., copper-and anionic-e.g., bilirubin-substances in the acidic and alkaline paths, respectively) and makes it ready for further binding. $\mathrm{pH}$ changes are possible by the addition of an acidic and an alkaline concentrate, whose customizable mixing relation forms a dialysate with a variable composition. This includes modifiable carbonate, sodium, or chloride concentrations that allow to achieve a customizable dialysate with a $\mathrm{pH}$ from 7.2 to 10.0. Consequently, this latter feature enables a continuous control and adjustment of dialysate acid-base properties, which in turn corrects deviations in blood $\mathrm{pH}$ (e.g., acidosis) by means of altering blood $\mathrm{pCO}_{2}$, strong ion difference, or both [18].

In the present study, the ability of ADVOS to eliminate $\mathrm{CO}_{2}$ and to correct blood $\mathrm{pH}$ was investigated in an ex vivo model of either lactic or hypercapnic acidosis, using porcine blood and a continuous supply of lactic acid and/or $\mathrm{CO}_{2}$, respectively. A variety of operational parameters, including blood and dialysate flows as well as different dialysate $\mathrm{pH}$ settings and acid and base concentrate compositions, were tested. In addition, comparisons with standard continuous veno-venous hemofiltration (CVVH) using high bicarbonate substitution fluid and continuous veno-venous hemodialysis (CVVHD) were performed. Finally, an analysis of the mechanism of action regarding classic and modern acid-base balance approaches is provided.

\section{Material and methods}

\section{Ex vivo model}

For all the experiments, an ex vivo model comprising 51 fresh porcine blood connected to an extracorporeal support device (either ADVOS multi, CVVH, or CVVHD) was employed. For experiments with ADVOS multi or CVVHD, an additional continuous $\mathrm{CO}_{2}$ supply was added. Small modifications comprising the administration of different solutions were performed for each specific experiment (Fig. 1).

\section{Blood preparation}

Fresh porcine blood was obtained from the local slaughterhouse (Münchner Schlachthof Betriebs GmbH, Munich, Germany) and prepared following a standard operation procedure (SOP) diluting it with modified Ringer's solution $(100 \mathrm{mmol} / \mathrm{l} \mathrm{NaCl}$, $3 \mathrm{mmol} / \mathrm{l} \mathrm{KCl}, 1 \mathrm{mmol} / \mathrm{l} \mathrm{MgSO}_{4} .7 \mathrm{H}_{2} \mathrm{O}, 1.75 \mathrm{mmol} / \mathrm{l} \mathrm{CaCl}, 1200 \mathrm{mg} / \mathrm{dl}$ glucose) to a hematocrit of $36 \%$, standard electrolyte concentrations, and normal blood gas values. 100,000 IU of heparin (Ratiopharm, Ulm, Germany) prevented coagulation. Blood was maintained at a constant temperature of $37^{\circ} \mathrm{C}$ using a bath heater while stirring it at 130-180 rpm.

\section{ADVOS system}

ADVOS multi

For the ADVOS system (ADVITOS GmbH, Munich, Germany), two SURELYZER PES190 DH dialyzers (Nipro D.Med Germany GmbH, Hamburg, Germany) with blood and dialysate flowing co-currently were employed in the extracorporeal circuit. Blood flow 
can be adjusted between 100 and $400 \mathrm{ml} / \mathrm{min}$. A dialysate flow of $800 \mathrm{ml} / \mathrm{min}$ was used throughout the study, which refers to the amount of fluid per minute being recirculated and detoxified in the ADVOS multi circuit by means of $\mathrm{pH}$ adjustments and filtration, instead of being discarded after a single pass. Variations of $\mathrm{pH}$ and composition are achieved using acidic and basic concentrates (see below). The concentrate flow (160 or $320 \mathrm{ml} / \mathrm{min}$ ) determines the quantity of dialysate cleaned by convective transport in the ADVOS multi circuit. Toxins released from albumin or water-soluble toxins are separated from the albumin dialysate through two ELISIO-13H filters (Nipro D.Med Germany GmbH. Hamburg, Germany). Additionally, the concentrate flow refers to the amount of new fresh concentrate (i.e., mix of water and acidic and alkaline concentrates) pumped into the system.

\section{$\mathrm{CO}_{2}$ administration for ADVOS multi and CVVHD experiments}

For this ex vivo model, $\mathrm{CO}_{2}$ was continuously infused into the blood pool via an additional SURELYZER PES-190 DH dialyzer (Nipro D.Med Germany GmbH, Hamburg, Germany) connected to a $\mathrm{CO}_{2}$ gas supply (Linde AG, Munich, Germany). Contrary to a standard dialyzer setup, in the $\mathrm{CO}_{2}$ dialyzer, blood was circulated through the external side to reduce the pressure within the blood circuit. $\mathrm{CO}_{2}$ was supplied to the inner side of the $\mathrm{CO}_{2}$ dialyzer in a countercurrent flow via a pressure reducer (FMD 202, Linde AG, Munich, Germany) and a mass flow meter FMA-1618A (OMEGA Engineering, Deckenpfronn, Germany). The bottom outlet of the $\mathrm{CO}_{2}$ dialyzer was closed to avoid $\mathrm{CO}_{2}$ losses while the semipermeable membrane allowed the gas to diffuse freely into the blood.

\section{Dialysate for ADVOS multi}

In contrast to other hemodialysis methods, the ADVOS system does not use a fixed dialysate composition. Instead, two concentrates (acid and base) are automatically mixed in a specifically designed reservoir throughout the treatment depending on the desired dialysate $\mathrm{pH}$ (range 7.20-10.00). A higher dialysate $\mathrm{pH}$ setting means a higher basic/ acidic concentrate ratio and thus higher sodium and lower chloride levels. Two $100 \mathrm{ml}$ bottles of albumin 20\% (Human Albumin $200 \mathrm{~g} / \mathrm{l}$, Baxter, Vienna, Austria) are added to the above dialysate mix via a specific port in the ADVOS multi device. The dialysate is furthermore supplemented with $40 \%$ glucose at an infusion rate of $70 \mathrm{ml} / \mathrm{h}$ to maintain glucose levels around $100 \mathrm{mg} / \mathrm{dl}$ in blood.

Acidic concentrate (AC) included $\mathrm{H}^{+}, \mathrm{Na}^{+}, \mathrm{Cl}^{-}, \mathrm{HPO}_{4}{ }^{2-}, \mathrm{Mg}^{2+}$, and $\mathrm{Ca}^{2+}$ while basic concentrate $(\mathrm{BC})$ consisted primarily of $\mathrm{OH}^{-}, \mathrm{Na}^{+}$, and $\mathrm{K}^{+}$. Two versions of $\mathrm{BC}$ were employed. BC-Bic20 contained $\mathrm{Na}_{2} \mathrm{CO}_{3}$, while $\mathrm{BC}$-Bic0 did not.

\section{Continuous veno-venous hemodialysis NIKKISO DBB-03}

The NIKKISO DBB-03 dialysis system (NIKKISO Europe GmbH, Langenhagen, Germany) consisted of a blood and dialysate circuit working as a single pass process without recirculating the dialysate. The dialysate flow $(350 \mathrm{ml} / \mathrm{min})$ determined the amount of dialysate being supplied and discarded. It was equipped with one SUREFLUX-25UX dialyzer (Nipro D.Med Germany GmbH, Hamburg, Germany) 
working with a countercurrent flow. Constant $\mathrm{HCO}_{3}{ }^{-}$and $\mathrm{Na}^{+}$concentrations in the dialysate were maintained by an integrated sodium bicarbonate cartridge ( $\mathrm{B}$. Braun Melsungen AG, Melsungen, Germany). Additionally, glucose $(1 \mathrm{~g} / \mathrm{l})$, potassium $(2 \mathrm{mmol} / \mathrm{l})$, and calcium $(1.5 \mathrm{mmol} / \mathrm{l})$ were infused into the reservoir.

\section{Continuous veno-venous hemofiltration}

\section{Sartorius Haemoprocessor 40040}

For standard CVVH system, the Haemoprocessor 40040 and its specific Plasma Line (Meise Medizintechnik GmbH, Schalksmühle, Germany) were connected to one SURELYZER PES-190 DH dialyzer (Nipro D.Med Germany GmbH, Hamburg, Germany). The multiPlus-CRRT solution containing $35 \mathrm{mmol} / \mathrm{l}$ of bicarbonate (Fresenius Medical Care, Bad Homburg, Germany) was employed as substitution solution in post-dilution mode. A blood flow of $200 \mathrm{ml} / \mathrm{min}$ was used for all experiments. The ultrafiltration and substitution flow rates were automatically adjusted by the device being always around $15 \mathrm{ml} / \mathrm{min}$ and $65 \mathrm{ml} / \mathrm{min}$, respectively.

\section{Experimental design}

Experiments were divided into three groups. First, blood was titrated with $\mathrm{CO}_{2}$ or lactic acid to achieve a blood $\mathrm{pH}$ range of 7.35-7.45 while being treated with ADVOS multi using different settings (set 1 and 2, respectively). Second, using a fixed $\mathrm{CO}_{2}$ or lactic acid supply, the performance of ADVOS multi vs. hemodialysis (CVVHD) or hemofiltration (CVVH) was compared (set 3 and set 4, respectively). Third, a hypercapnic acidosis was triggered in blood and further treated with ADVOS multi until recovery of normal blood gas values. Details for each of the experimental sets are summarized in Table 1.

\section{Set 1: Influence of ADVOS multi operational settings on $\mathrm{CO}_{2}$ removal}

In order to determine the influence of blood flow and dialysate composition on $\mathrm{CO}_{2}$ removal ability of the ADVOS system, different settings were tested during a continuous $\mathrm{CO}_{2}$ supply (Fig. 1). Briefly, $5 \mathrm{l}$ of blood at physiological levels of $\mathrm{pH}$ (7.35-7.45), $\mathrm{HCO}_{3}{ }^{-}(22-28 \mathrm{mmol} / \mathrm{l})$, and $\mathrm{pCO}_{2}(35-45 \mathrm{mmHg})$ was treated with ADVOS multi at experimental blood flows $\left(\mathrm{Q}_{\mathrm{b}}\right)$ of 100,200 , or $400 \mathrm{ml} / \mathrm{min}$ with co-currently recirculating dialysate at flows of $800 \mathrm{ml} / \mathrm{min}$. At each $\mathrm{Q}_{\mathrm{b}}$, dialysate $\mathrm{pH}$ was set to $7.5,8.0,8.5$, and 9.0 using a concentrate flow $\left(\mathrm{Q}_{\mathrm{c}}\right)$ of $160 \mathrm{ml} / \mathrm{min}$. At the highest $\mathrm{Q}_{\mathrm{b}}$ of $400 \mathrm{ml} / \mathrm{min}$, additional tests were carried out with a $\mathrm{Q}_{\mathrm{c}}$ of $320 \mathrm{ml} / \mathrm{min}$. All these experiments were carried out using the concentrates $\mathrm{AC}$ and $\mathrm{BC}-\mathrm{Bic} 20$.

With the intention to test if different bicarbonate concentrations of the dialysate might affect $\mathrm{CO}_{2}$ removal, additional experiments with $\mathrm{BC}-\mathrm{Bic} 0$ (without bicarbonate) instead of $\mathrm{BC}$-Bic20 were carried out setting dialysate $\mathrm{pH}$ to 10.00 .

Prior to blood hemodialysis, every dialyzer was primed with a $0.9 \% \mathrm{NaCl}$ solution removing air before blood contact. The $\mathrm{CO}_{2}$ dialyzer was flushed with gas prior to and during $\mathrm{NaCl}$ and blood perfusion to create a positive pressure gradient which prevented liquids from entering the capillaries. Every test consisted of a 20-min stabilization period during which $\mathrm{CO}_{2}$ supply was adjusted such that blood $\mathrm{pH}$ remained between 7.35 and 7.45 . This was followed by a 1-h treatment phase during which samples from 
Table 1 Experimental setting for each of the tests performed

\begin{tabular}{|c|c|c|c|c|c|c|c|}
\hline \multirow[b]{2}{*}{ Supply } & \multirow[t]{2}{*}{ Set 1} & \multirow[t]{2}{*}{ Set 2} & \multicolumn{2}{|c|}{ Set 3} & \multicolumn{2}{|c|}{ Set 4} & \multirow[t]{2}{*}{ Set 5} \\
\hline & & & & & & & \\
\hline $\mathrm{CO}_{2}(\mathrm{ml} / \mathrm{min})$ & (1) & (2) & 110 & 110 & (1) & No & 27 \\
\hline Lactic acid (mmol/min) & No & (3) & No & No & 0.5 & 0.5 & No \\
\hline \multicolumn{8}{|l|}{ Device settings } \\
\hline Treatment & ADVOS & ADVOS & ADVOS & CWHD & ADVOS & $\mathrm{CWH}$ & ADVOS \\
\hline Blood flow (ml/min) & $100,200,400$ & $100,200,400$ & 400 & 400 & 200 & 200 & 200 \\
\hline $\begin{array}{l}\text { Single pass dialysate } \\
\text { flow }(\mathrm{ml} / \mathrm{min})\end{array}$ & n.a. & n.a. & n.a. & 350 & n.a. & n.a. & n.a. \\
\hline $\begin{array}{l}\text { Recirculating dialysate } \\
\text { flow }(\mathrm{ml} / \mathrm{min})^{*}\end{array}$ & 800 & 800 & 800 & n.a. & 800 & n.a. & 800 \\
\hline Concentrate flow $(\mathrm{ml} / \mathrm{min})^{* *}$ & 160,320 & 320 & 320 & n.a. & 160 & n.a. & 160 \\
\hline $\begin{array}{l}\text { Replacement solution } \\
\text { flow }(\mathrm{ml} / \mathrm{min})\end{array}$ & n.a. & n.a. & n.a. & n.a. & n.a. & 65 & n.a. \\
\hline Ultrafiltration flow (ml/min) & n.a. & n.a. & n.a. & n.a. & n.a. & 15 & n.a. \\
\hline $\begin{array}{l}\text { Dialysate/replacement } \\
\text { solution } \mathrm{pH}\end{array}$ & $\begin{array}{l}7.5,8.0,8.5 \\
9.0,10.0\end{array}$ & $\begin{array}{l}7.5,8.0 \\
8.5,9.0\end{array}$ & 10.0 & 8.0 & 9.0 & 7.4 & 9.0 \\
\hline Dialyzer surface $\left(\mathrm{m}^{2}\right)$ & $2 \times 1.9$ & $2 \times 1.9$ & $2 \times 1.9$ & 2.5 & $2 \times 1.9$ & 1.9 & $2 \times 1.9$ \\
\hline $\begin{array}{l}\text { Alkaline concentrate } \\
\text { (during treatment phase) }\end{array}$ & BC-Bic20, BC-Bic0 & BC-Bic20 & BC-Bic0 & n.a. & BC-Bic20 & n.a. & $\mathrm{BC}-\mathrm{BiCO}$ \\
\hline \multicolumn{8}{|l|}{$\begin{array}{l}\text { Blood baseline levels (before } \\
\text { treatment phase) }\end{array}$} \\
\hline $\mathrm{pH}$ & $7.35-7.45$ & $7.35-7.45$ & $7.35-7.45$ & $7.35-7.45$ & $<7.15$ & $<7.15$ & $<7.15$ \\
\hline $\mathrm{pCO}_{2}(\mathrm{mmHg})$ & $35-45$ & $35-45$ & $35-45$ & $35-45$ & $35-45$ & $35-45$ & $>60$ \\
\hline $\mathrm{HCO}_{3}^{-}(\mathrm{mmol} / \mathrm{l})$ & $22-28$ & $22-28$ & $22-28$ & $22-28$ & $12-14$ & $12-14$ & $>32$ \\
\hline Lactate (mmol/l) & n.a. & n.a. & n.a. & n.a. & $5-6$ & $5-6$ & n.a. \\
\hline $\begin{array}{l}\text { Number of experiments } \\
\text { performed }\end{array}$ & 3 & 3 & 6 & 6 & 3 & 3 & 2 \\
\hline
\end{tabular}

n.a. not applicable

${ }^{(1)} \mathrm{CO}_{2}$ supply was adjusted such that blood $\mathrm{pH}$ remained between 7.35 and 7.45

${ }^{(2)} \mathrm{CO}_{2}$ was continuously infused on demand to maintain $\mathrm{pCO}_{2}$ levels between 35 and $45 \mathrm{mmHg}$

${ }^{(3)} \mathrm{A}$ continuous $2 \%$ lactic acid solution was infused such that blood pH remained between 7.35 and 7.45

*The recirculating dialysate flow in the ADVOS system reflects the volume of dialysate that recirculates continuously (not discarded)

**The concentrate flow corresponds to the dialysate flow of a conventional single pass dialysis device and reflects the amount of dialysate used and discarded

***Experiments performed with each combination of blood flow, concentrate flow, and dialysate $\mathrm{pH}$

the inlet (pre-dialyzer) and outlet (post-dialyzer) were analyzed by the blood gas analyzer GEM Premier 4000 (Instrumentation Laboratory, Munich, Germany) every $20 \mathrm{~min}$. In addition, $\mathrm{pH}$ was measured by an InPro $3253 \mathrm{pH}$ probe inserted into the blood container and M300 displayed it continuously (both Mettler Toledo, Greifersee, Switzerland).

To quantify $\mathrm{CO}_{2}$ removal in milliliters per minute, post-dialyzer $\mathrm{TCO}_{2}$ values in millimoles per liter were subtracted from pre-dialyzer values and this difference multiplied by the corresponding blood flow $\left(\mathrm{Q}_{\mathrm{b}}\right)$ and by the molar volume $\left(\mathrm{V}_{\mathrm{m}}\right)$ of $\mathrm{CO}_{2}$ at STP (22.4 $\mathrm{ml} / \mathrm{mmol}$ ) (Eq. 1). The fraction of $\mathrm{TCO}_{2}$ excreted as dissolved $\mathrm{CO}_{2}$ or $\mathrm{HCO}_{3}{ }^{-}$was calculated likewise [19].

$$
\mathrm{TCO}_{2} \text { removal }(\mathrm{ml} / \mathrm{min})=\left(\mathrm{TCO}_{2} \text { pre }-\mathrm{TCO}_{2} \text { post }\right) * Q_{b} * V_{m}
$$




\section{Set 2: Influence of ADVOS multi operational settings on blood $\mathrm{pH}$ during continuous acid load}

The same experimental design as for set 1 was performed to determine the influence of ADVOS parameters, with small modifications. Briefly, a continuous $2 \%$ lactic acid solution was used to titrate blood $\mathrm{pH}$ to $7.35-7.45 . \mathrm{CO}_{2}$, instead, was continuously infused on demand to maintain $\mathrm{pCO}_{2}$ levels between 35 and $45 \mathrm{mmHg}$. These experiments were only carried out with $\mathrm{Q}_{\mathrm{c}}$ of $320 \mathrm{ml} / \mathrm{min}$ and with BC-Bic20.

For each experiment, the maximal combined acid supply resulting from lactic acid infusion and $\mathrm{CO}_{2}$ influx supply was calculated from the infusion rate of the pump (Volumat MC Agilia. Fresenius Kabi, Bad Homburg, Germany) and reading of the mass flow meter FMA-1618A (OMEGA Engineering, Deckenpfronn, Germany), respectively.

\section{Set 3: ADVOS multi vs. CVVHD during continuous maximal $\mathrm{CO}_{2}$ supply}

The maximum $\mathrm{CO}_{2}$ supply was determined previously in set 1 to be $110 \mathrm{ml} / \mathrm{min}$ (Additional file 1: Table S1). Blood was treated for $4 \mathrm{~h}$ with either the ADVOS multi or the CVVHD device NIKKISO DBB-03. The settings for each device are detailed in Table 1. Blood gas analysis was performed every $15 \mathrm{~min}$.

\section{Set 4: ADVOS multi vs. CVVH for the treatment of lactic acidosis in vitro}

First, 51 of fresh swine blood was subjected to CVVH with a substitution fluid with $10 \mathrm{mmol} / \mathrm{l}$ bicarbonate. Simultaneously, a $2 \%$ lactic acid solution was infused in order to reach a $\mathrm{pH}<7.15$, a $\mathrm{pCO}_{2}$ between 35 and $45 \mathrm{mmHg}, \mathrm{HCO}_{3}{ }^{-}$levels between 12 and $14 \mathrm{mmol} / \mathrm{l}$, and lactate of $5-6 \mathrm{mmol} / \mathrm{l}$, which simulated a severe lactic acidosis. Blood was then treated with either ADVOS multi or CVVH for $1 \mathrm{~h}$. Lactic acid infusion was maintained during the treatment phase. Blood was analyzed as described above.

\section{Set 5: Treatment of hypercapnic acidosis in vitro with ADVOS multi}

In this case, a hypercapnic acidosis was triggered first. Briefly, $27 \mathrm{ml} / \mathrm{min} \mathrm{CO}_{2}$ was infused while a blood flow of $100 \mathrm{ml} / \mathrm{min}$ and a dialysate $\mathrm{pH}$ of 7.8 were set. During this phase, $\mathrm{AC}$ was combined with $\mathrm{BC}$-Bic20. Once a $\mathrm{pH}<7.15$, a $\mathrm{pCO}_{2}>60 \mathrm{mmHg}$, and $\mathrm{HCO}_{3}{ }^{-}$levels $>32 \mathrm{mmol} / \mathrm{l}$ were reached, both the settings and the $\mathrm{BC}$ were changed, and the treatment phase started. Blood was then treated with ADVOS multi until normal values of $\mathrm{pH}$ (7.35-7.45), $\mathrm{pCO}_{2}$ (35-45 $\left.\mathrm{mmHg}\right)$, and $\mathrm{HCO}_{3}{ }^{-}(22-26 \mathrm{mmol} / \mathrm{l})$ were detected. Blood values were analyzed as described above. $\mathrm{CO}_{2}$ was continuously supplied with the same flow of $27 \mathrm{ml} / \mathrm{min}$.

\section{Acid-base balance according to Stewart}

We obtained blood samples both at the inlet and the outlet of the dialyzers from experimental sets 1 and 2. The analysis of these data provides an understanding of $\mathrm{pH}$ variations attending to $\mathrm{pCO}_{2}$ and SID changes. In order to better understand this physicochemical method proposed by Stewart [20], several authors have tried to calculate specific values for the total concentration and the effective dissociation constant for plasma nonvolatile buffers. Constable suggested that "at normal pH (7.40), a 1-meq/l increase in SID will increase $\mathrm{pH}$ by 0.016 , a 1 -Torr increase in $\mathrm{pCO}_{2}$ will decrease $\mathrm{pH}$ by 0.009 , and a $1 \mathrm{~g} / \mathrm{dl}$ increase in total protein will decrease $\mathrm{pH}$ by 0.039 " [21]. It is 
assumed that no variation on total protein content occurs in our setting as it cannot be lost in the dialyzer. Therefore, variations in $\left[\mathrm{A}_{\text {tot }}\right]$ (i.e., total protein) are not considered within the equation that was employed to predict the resulting outlet $\mathrm{pH}$.

Equation 2. Calculated $\mathrm{pH}$ in the outlet of the dialyzer based on measured values of $\mathrm{pH}, \mathrm{SID}$, and $\mathrm{pCO}_{2}$, adapted from [21]:

$$
\begin{aligned}
\mathrm{pH} \text { outlet }= & \mathrm{pH} \text { inlet }+0.016 \times(\text { SID outlet }- \text { SID inlet })-0.009 \\
& \times\left(\mathrm{pCO}_{2} \text { outlet }-\mathrm{pCO}_{2} \text { inlet }\right)
\end{aligned}
$$

\section{Statistics}

Experiments were performed at different settings between 3 and 6 times each covering a wide range of operational parameters. Student's $t$ test for paired samples was used to compare $\mathrm{CO}_{2}$ removal and acid supply between different ADVOS settings for experimental sets 1 and 2, respectively. A two-tailed $p$ value lower than 0.05 was considered to indicate statistical significance. For correlations assessment, Pearson's coefficient was employed. Data were documented and analyzed using Microsoft Excel and IBM SPSS 24.0 for Windows ${ }^{\circ}$, respectively. Data are presented as mean \pm standard deviation (SD)

\section{Results}

Influence of ADVOS multi operational settings on $\mathrm{CO}_{2}$ removal

In this experimental design, where blood was titrated with $\mathrm{CO}_{2}$ to maintain a blood $\mathrm{pH}$ between 7.35 and 7.45, $\mathrm{CO}_{2}$ removal with ADVOS multi depended on three variables: (1) the amount of $\mathrm{CO}_{2}$ being supplied, (2) the blood flow, and (3) the dialysate composition (i.e., according to carbonate concentration and dialysate $\mathrm{pH}$ setting) (Fig. 2 and Additional file 1: Table S1). During experiments with BC-Bic20 and $\mathrm{Q}_{\mathrm{c}}$ of $160 \mathrm{ml} / \mathrm{min}$, higher $\mathrm{Q}_{\mathrm{b}}$ resulted in higher $\mathrm{CO}_{2}$ elimination with an average of $77 \pm 22 \mathrm{ml} / \mathrm{min}$ at $\mathrm{Q}_{\mathrm{b}}$ $400 \mathrm{ml} / \mathrm{min}$ with a dialysate of $\mathrm{pH} 9.0$. With the same dialysate $\mathrm{pH}, 35$ and $19 \mathrm{ml} / \mathrm{min}$ of $\mathrm{CO}_{2}$ were removed at $\mathrm{Q}_{\mathrm{b}} 200$ and $100 \mathrm{ml} / \mathrm{min}$, respectively. A lower dialysate $\mathrm{pH}$ setting (i.e., lower sodium and higher chloride) resulted in lower $\mathrm{CO}_{2}$ removal, independently of any other setting. In fact, the dialysate composition (i.e., the presence of albumin and sodium and chloride concentrations) together with the dialysate $\mathrm{pH}$ (but not dialysate $\mathrm{pH}$ alone) is responsible for blood $\mathrm{pH}$ correction.

At a $\mathrm{Q}_{\mathrm{c}}$ of $160 \mathrm{ml} / \mathrm{min}$ compared to $320 \mathrm{ml} / \mathrm{min}$, setting dialysate $\mathrm{pH}$ to 9.0 resulted in significantly higher blood $\mathrm{HCO}_{3}{ }^{-}(57.0 \pm 10.2$ vs. $38.5 \pm 2.8 \mathrm{mmol} / \mathrm{l})$ and $\mathrm{pCO}_{2}$ (103 \pm 17 vs. $74 \pm 4 \mathrm{mmHg}$ ), which is correlated with the higher amount of $\mathrm{CO}_{2}$ removed (Additional file 1: Table S1).

Increasing the $\mathrm{Q}_{\mathrm{c}}$ from $160 \mathrm{ml} / \mathrm{min}$ to $320 \mathrm{ml} / \mathrm{min}$ means doubling the convective transport, which results in faster removal of substances diffused from blood (e.g., bicarbonate). Therefore, at higher concentrate flows, a more efficient concentration gradient between blood and dialysate is available, resulting, in this case, in lower blood baseline levels of $\mathrm{HCO}_{3}{ }^{-}$with a $\mathrm{Q}_{\mathrm{c}}$ of $320 \mathrm{ml} / \mathrm{min}$ in comparison to a $\mathrm{Q}_{\mathrm{c}}$ of $160 \mathrm{ml} / \mathrm{min}$. Lower blood $\mathrm{HCO}_{3}{ }^{-}$can buffer less acid in blood (i.e., less $\mathrm{CO}_{2}$ can be supplied without altering blood $\mathrm{pH}$ ), which, due to the lower total $\mathrm{CO}_{2}$ concentration in blood (i.e., lower $\mathrm{pCO}_{2}$ at the inlet of the dialyzer), it was translated in a lower $\mathrm{CO}_{2}$ removal in our experimental setting. Nevertheless, this is an artefactual result caused by the experimental 


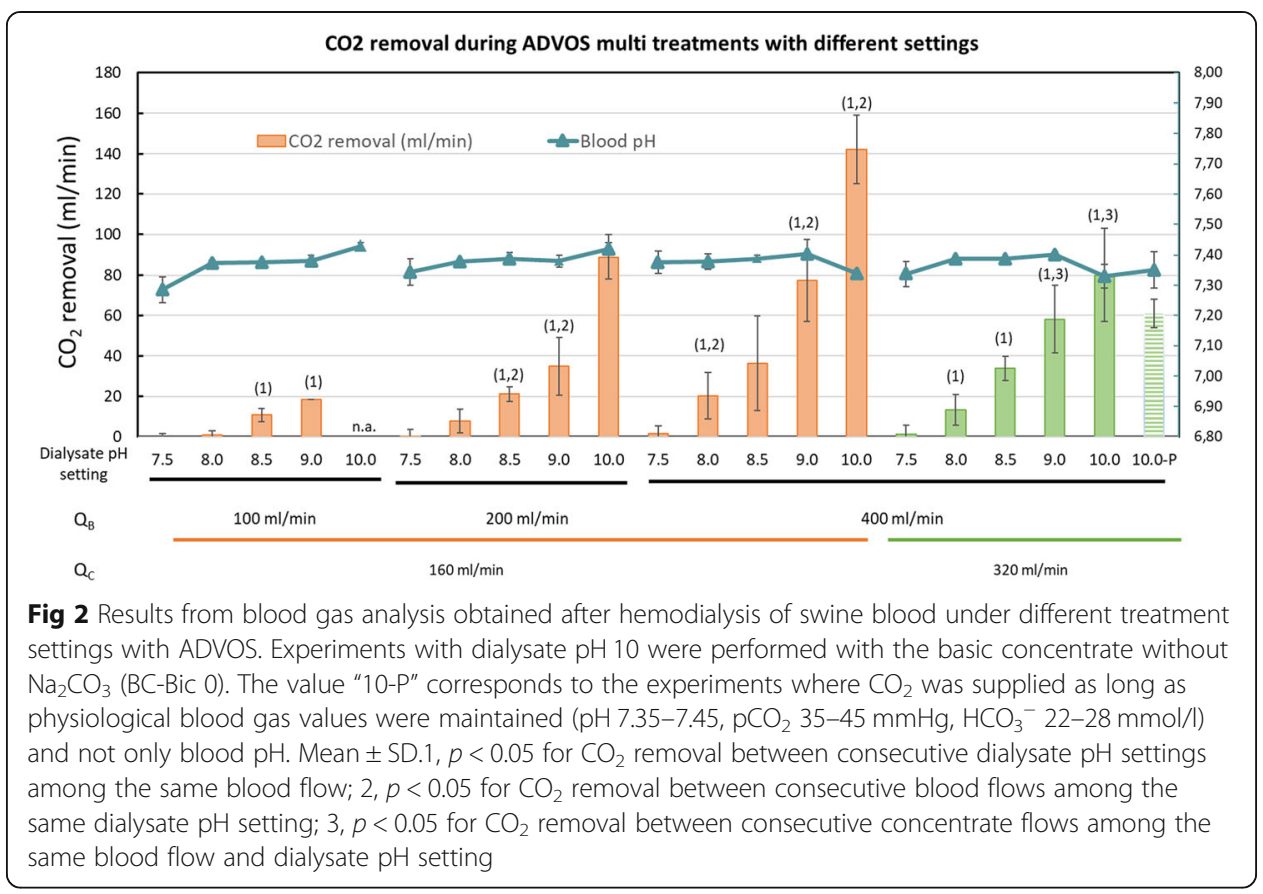

design as not $\mathrm{Q}_{\mathrm{c}}$, but $\mathrm{Q}_{\mathrm{b}}, \mathrm{CO}_{2}$ supply, and dialysate $\mathrm{pH}$ setting affect the $\mathrm{CO}_{2}$ removal capacity.

In line with these results, using a carbonate-free dialysate $\mathrm{BC}$ - $\mathrm{Bic} 0$ with dialysate $\mathrm{pH}$ set to 10, a maximum removal of $142 \mathrm{ml} / \mathrm{min} \mathrm{CO}_{2}$ was achieved during ADVOS treatment with $\mathrm{Q}_{\mathrm{b}}$ of $400 \mathrm{ml} / \mathrm{min}$ and $\mathrm{Q}_{\mathrm{c}}$ of $160 \mathrm{ml} / \mathrm{min}$. However, with this setting, $\mathrm{pCO}_{2}$ and $\mathrm{HCO}_{3}{ }^{-}$were extremely above physiological levels $(117 \pm 5 \mathrm{mmHg}$ and $62.8 \pm 3.4$ $\mathrm{mmol} / \mathrm{l}$, respectively). Thus, blood was then titrated with $\mathrm{CO}_{2}$ only as long as every blood gas value was maintained within a physiological range (including $\mathrm{pCO}_{2}$ and $\mathrm{HCO}_{3}{ }^{-}$). This setting allowed a $\mathrm{CO}_{2}$ removal of $61 \mathrm{ml} / \mathrm{min}$ using a $\mathrm{Q}_{\mathrm{b}}$ of $400 \mathrm{ml} / \mathrm{min}$ and a $\mathrm{Q}_{\mathrm{c}}$ of $320 \mathrm{ml} / \mathrm{min}$. This was only possible with a basic concentrate without carbonate. In fact, similar $\mathrm{CO}_{2}$ removal rates were achieved with the same flows and with dialysate $\mathrm{pH} 9$ with the $\mathrm{BC}$-Bic20 concentrate $(58 \mathrm{ml} / \mathrm{min})$, but blood gas levels were above physiological values in this case (Fig. 2 and Additional file 1: Table S1).

Variations between the inlet (pre) and the outlet (post) of the dialyzers for SID, $\mathrm{pCO}_{2}, \mathrm{HCO}_{3}{ }^{-}$, and $\mathrm{pH}$ are shown in Additional file 1: Table S1.

\section{Influence of ADVOS multi operational settings on blood pH during continuous acid load}

Experiments with ADVOS multi employing different operational settings showed that higher blood flows and dialysate $\mathrm{pH}$ settings were able to allow higher acid loads. The influence of each parameter is shown in Fig. 3. These results show a low level of $\mathrm{CO}_{2}$ removal needed $(<1 \mathrm{mmol} / \mathrm{min}$ or $22.5 \mathrm{ml} / \mathrm{min})$ to maintain $\mathrm{pCO}_{2}$ stable $(35-45 \mathrm{mmHg})$ in those cases where $\mathrm{CO}_{2}$ elimination is not required.

Variations between the inlet (pre) and the outlet (post) of the dialyzers for SID, $\mathrm{pCO}_{2}, \mathrm{HCO}_{3}{ }^{-}$, and $\mathrm{pH}$ are shown in Additional file 1: Table S2. 


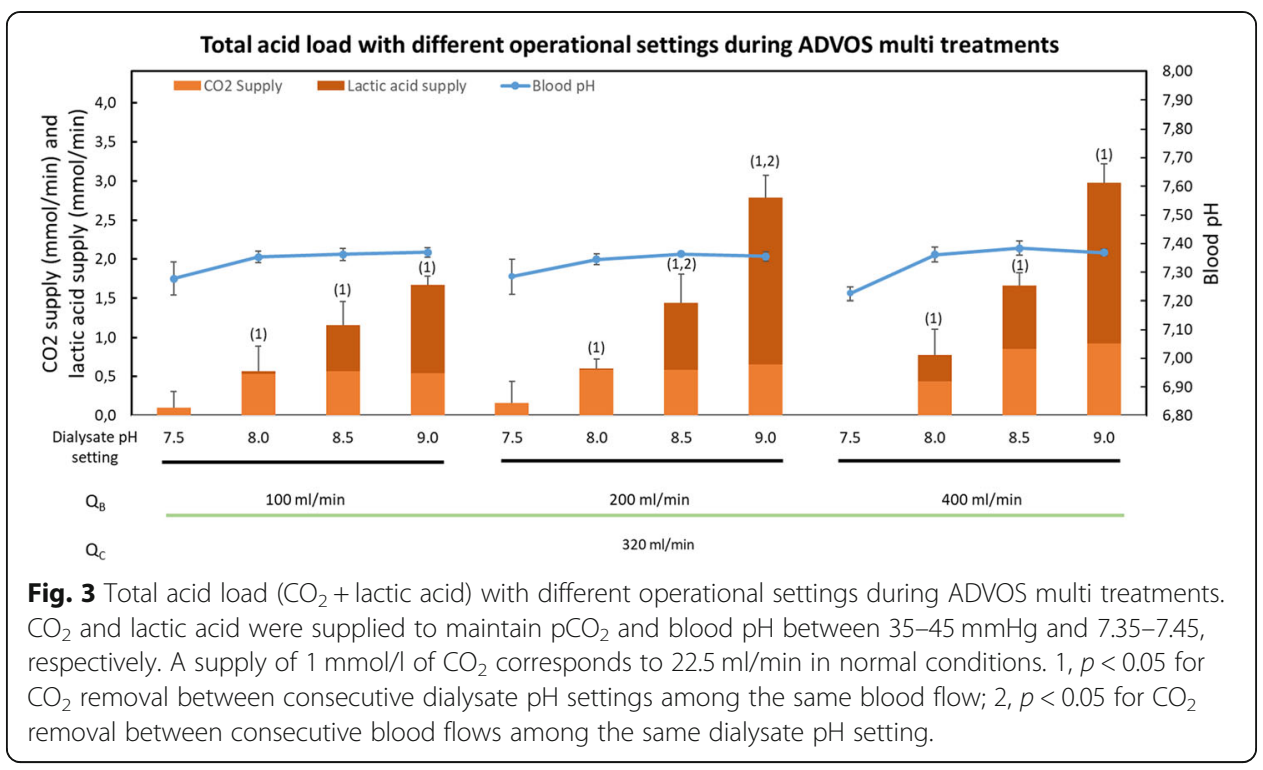

ADVOS multi vs. CVVHD during continuous maximal $\mathrm{CO}_{2}$ supply

Using a carbonate-free dialysate with a $\mathrm{pH}$ of 10 , ADVOS multi removed $79 \pm 1 \mathrm{ml} / \mathrm{min}$ $\mathrm{TCO}_{2}$ on average during $4 \mathrm{~h}$ of continuous supply of $110 \mathrm{ml} / \mathrm{min} \mathrm{CO}_{2}$. Blood $\mathrm{pCO}_{2}$ $(66 \pm 9 \mathrm{mmHg})$ and $\mathrm{HCO}_{3}{ }^{-}(33.1 \pm 0.1 \mathrm{mmol} / \mathrm{l})$ levels were stable throughout the experiments. The ADVOS device was able to maintain $\mathrm{pH}$ stable and within the physiological range (Fig. 4) while post-dialyzer $\mathrm{pH}$ remained always below 8 .

In contrast, despite identical $\mathrm{CO}_{2}$ influx, blood $\mathrm{pH}$ dropped already 15 min after circulating blood through the NIKKISO renal dialysis device reaching a constant $\mathrm{pH}$ of around 6.60 after $1 \mathrm{~h}$. Post-dialyzer $\mathrm{pH}$ remained below 7 during the experiment.

\section{Treatment of metabolic acidosis in vitro: ADVOS multi vs. CVVH}

Once metabolic acidosis was triggered (minute 40, Fig. 5), bicarbonate therapy during $\mathrm{CVVH}$ was able to normalize $\mathrm{HCO}_{3}{ }^{-}$levels. However, as expected, due to the lack of ventilation, $\mathrm{pCO}_{2}$ was correspondingly elevated $(>90 \mathrm{mmHg}$ ) resulting in an even lower $\mathrm{pH}(<7.00)$ after the treatment. Conversely, ADVOS multi normalized $\mathrm{pH}$ and bicarbonate levels in less than $1 \mathrm{~h}$. Due to the high $\mathrm{CO}_{2}$ removal ability of the ADVOS system when dialysate $\mathrm{pH}$ is set to 9.0 , even $15 \mathrm{ml} / \mathrm{min}$ of $\mathrm{CO}_{2}$ was additionally provided during the treatment with ADVOS multi to maintain blood $\mathrm{pH}$ between 7.35 and 7.45 .

\section{Treatment of hypercapnic acidosis in vitro with ADVOS multi}

Using a basic concentrate without $\mathrm{Na}_{2} \mathrm{CO}_{3}$ (BC-Bic 0), ADVOS multi was able to restore a hypercapnic acidosis in vitro in less than $30 \mathrm{~min}$ using a $\mathrm{Q}_{\mathrm{b}}$ of $200 \mathrm{ml} / \mathrm{min}$, a $\mathrm{Q}_{\mathrm{c}}$ of $160 \mathrm{ml} / \mathrm{min}$, and dialysate $\mathrm{pH}$ set to 9.0 during a continuous supply of $27 \mathrm{ml} / \mathrm{min}$ of $\mathrm{CO}_{2}$. After changing the settings (dialysate $\mathrm{pH} 7.8$ vs. 9.0) and the basic concentrate (BC-Bic 20 vs. $\mathrm{BC}-\mathrm{Bic} 0$ ), values of $\mathrm{pH}$ (7.12 vs. 7.35 ), $\mathrm{pCO}_{2}$ (99 vs. $40 \mathrm{mmHg}$ ), and $\mathrm{HCO}_{3}{ }^{-}$(32.7 vs. $22.6 \mathrm{mmol} / \mathrm{l}$ ) returned to physiological standards (Fig. 6). 


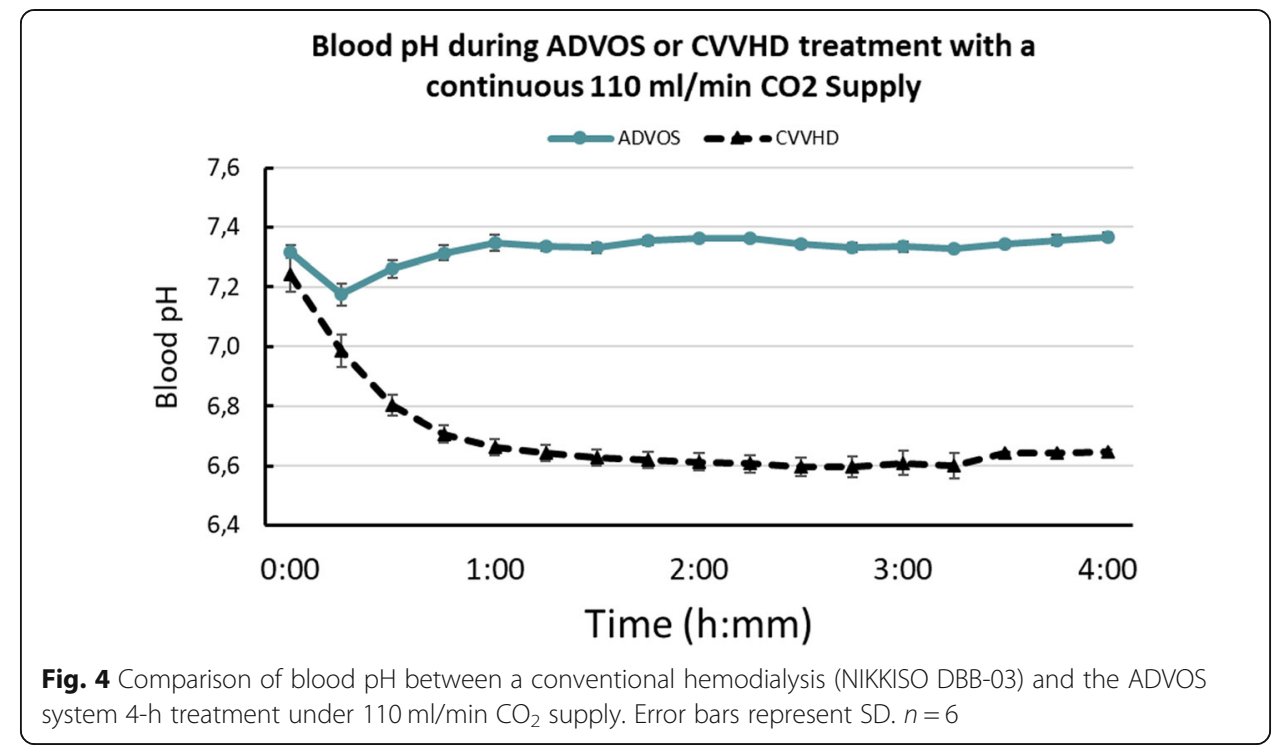

\section{Acid-base balance according to Stewart}

As shown in Additional file 1: Tables $\mathrm{S} 1$ and $\mathrm{S} 2$, the higher the $\mathrm{pCO}_{2}$ reduction, the higher the $\mathrm{pH}$ increase that can be achieved in blood, describing a direct correlation for more than 200 blood samples in both experimental sets 1 and 2 (Additional file 2: Figure S1 $r^{2}=0.812$ and Additional file 2:Figure S2 $r^{2}=0.935$, respectively).

To note, to increase the dialysate $\mathrm{pH}$, the ratio "basic concentrate/acidic concentrate" increases. Attending to the composition of these solutions, an increase in the basic/ acidic concentrate ratio results in a dialysate with higher sodium and lower chloride concentrations. Indeed, an increase in SID was observed for set 1 (Additional file 1: Table S1), but not for set 2 due to the lactate addition (Additional file 1: Table S2).

Finally, we were able to predict $\mathrm{pH}$ variations solely by measuring SID and $\mathrm{pCO}_{2}$ changes (Additional file 2: Figures S1 and S2; Additional file 3: Figures S3 and S4; Additional file 4: Figures S5 and S6). The calculated values correlated perfectly with measured values $\left(r^{2}=0.98\right)$. Variations in total protein are not expected since no albumin loss occurs in the dialyzer.

\section{Discussion}

In the present study, the ability of an albumin hemodialysis system (ADVOS multi) to correct hypercapnic and lactic acidosis in vitro has been demonstrated. Different settings can be varied in this device (blood flow, concentrate flow, carbonate content, and dialysate $\mathrm{pH}$ ), allowing different rates of $\mathrm{CO}_{2}$ removal or acid load. This is only possible due to the presence of albumin in the dialysate, which permits to alter the composition of the dialysate (including the strong ion difference and the $\mathrm{CO}_{2}$ content). A concentrate gradient between blood and dialysate for electrolytes or bicarbonate is then possible, allowing the correction of acidosis from hypercapnic or metabolic origin.

\section{Lung support through $\mathrm{CO}_{2}$ removal}

The lung removes $\mathrm{CO}_{2}$ directly, thanks to the fast transformation of $\mathrm{H}^{+}+\mathrm{HCO}_{3}{ }^{-}$ through carbonic anhydrase into $\mathrm{CO}_{2}$ gas and water. However, in blood, $\mathrm{CO}_{2}$ is mainly 


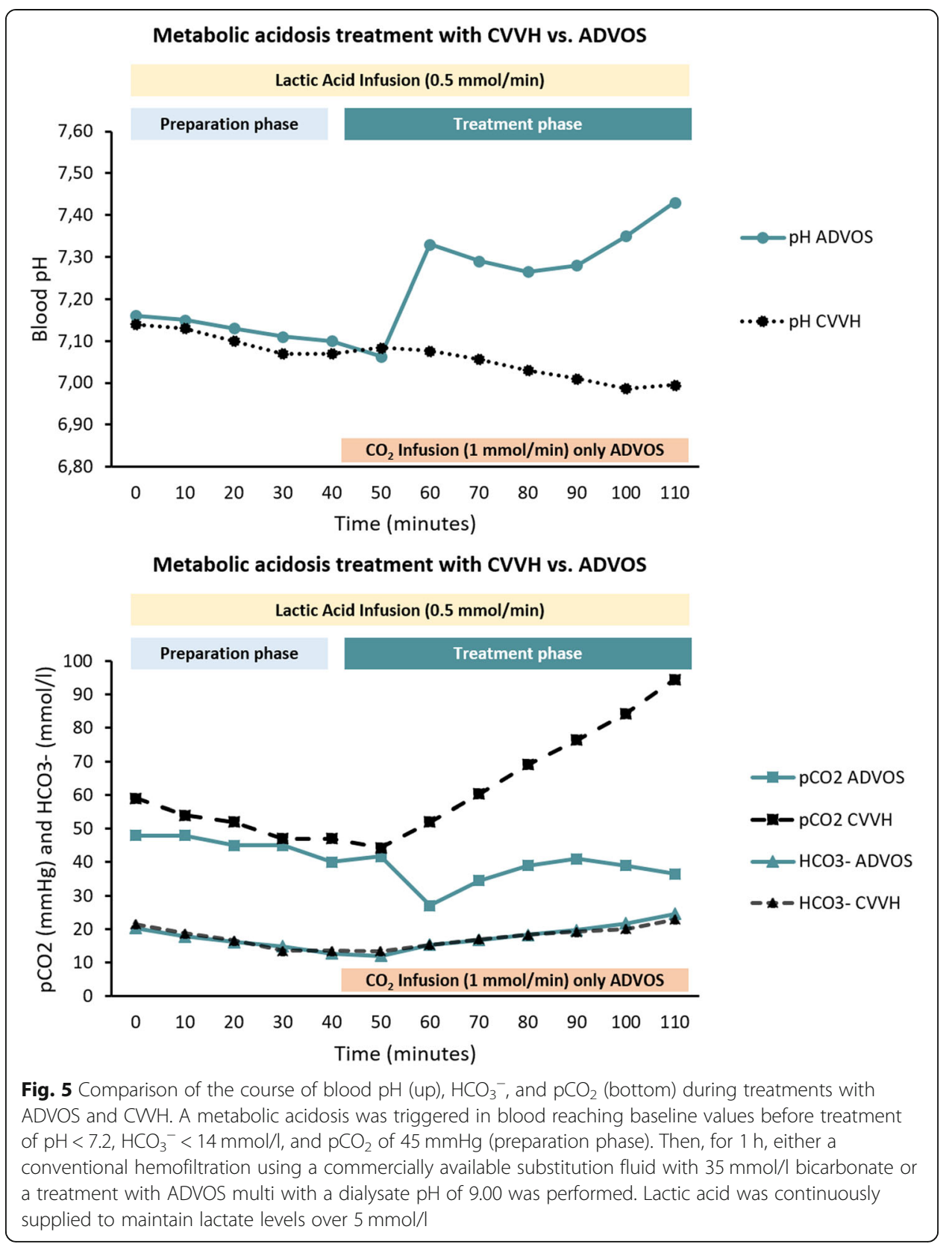

found as $\mathrm{HCO}_{3}{ }^{-}$. ADVOS reduces $\mathrm{pCO}_{2}$ through the removal of $\mathrm{HCO}_{3}{ }^{-}$by forming a concentration gradient between blood and dialysate. Additionally, the high dialysate $\mathrm{pH}$ helps to reduce the $\mathrm{H}^{+}$concentration in blood and thus increase the $\mathrm{pH}$. This is possible due to the presence of albumin in the dialysate. Albumin increases the buffer capacity via a protonation of its imidazole side chain [22], which contains several buffering residues of histidine [23, 24]. Preliminary in-house studies indicate that a dialysate of pH 9 containing two $100 \mathrm{ml}$ bottles of albumin $20 \%$ increased the buffer capacity by $35 \%$ compared to the same dialysate without albumin (Additional file 5: Figure S7).

Bearing this in mind, first, a higher blood flow may account for a higher $\mathrm{HCO}_{3}{ }^{-}$ concentration gradient between blood and dialysate (i.e., $400 \mathrm{ml} / \mathrm{min}$ ). Second, a higher dialysate $\mathrm{pH}$ (with a higher SID) allows a higher decrease in $\mathrm{H}^{+}$concentration (i.e., 


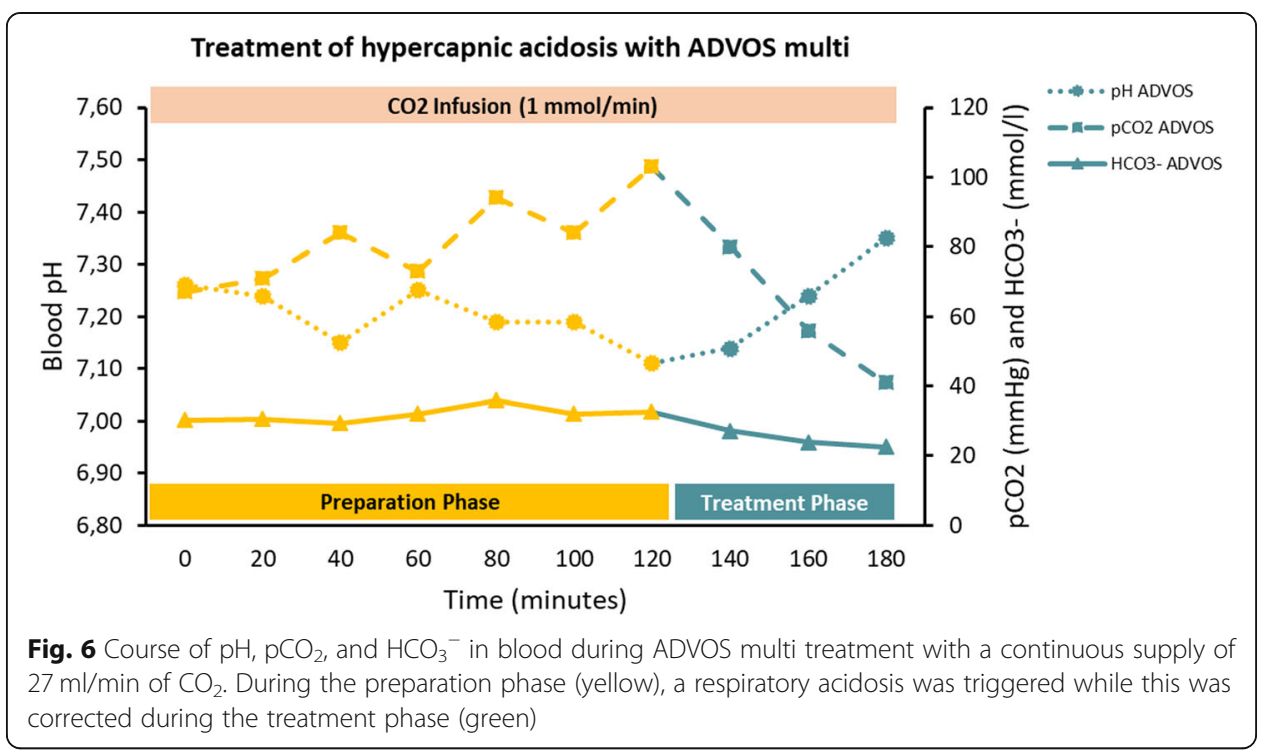

dialysate $\mathrm{pH}$ 10). Third, lower (or none) dialysate carbonate levels permit a more effective convective transport in the ADVOS multi circuit (Fig. 1). Finally, this convective transport will be faster insofar a higher concentrate flow is set (i.e., $320 \mathrm{ml} / \mathrm{min}$ ) (Fig. 2 and Additional file 1: Table S1). Even at lower blood and concentrate flows (200 and $160 \mathrm{ml} / \mathrm{min}$, respectively) and with dialysate $\mathrm{pH}$ set to 9 , the use of a dialysate without carbonate allowed a correction of hypercapnic acidosis in vitro in less than $1 \mathrm{~h}$ (Fig. 6).

\section{Kidney support through $\mathrm{HCO}_{3}{ }^{-}$generation}

The renal compensatory mechanism during a respiratory acidosis tries to increase the acid excretion into urine and the $\mathrm{HCO}_{3}{ }^{-}$resorption into blood [25]. When using a bicarbonate containing dialysate with high $\mathrm{pH}$, this mechanism is mimicked by ADVOS.

This can be explained following the $\mathrm{CO}_{2}$ equilibrium in Eq. 3. Carbonic acid, or $\mathrm{CO}_{2}$ in its gas form, is converted to $\mathrm{HCO}_{3}{ }^{-}$and $\mathrm{H}^{+}$. The reduction of $\mathrm{H}^{+}$concentration in blood forces the equilibrium to the right of the equation, increasing $\mathrm{HCO}_{3}{ }^{-}$even as it is removed from blood, and consequently, $\mathrm{CO}_{2}$ is transferred down its concentration gradient from the intracellular space (i.e., correcting intracellular acidosis) into the blood and into the dialysate in the form of $\mathrm{HCO}_{3}{ }^{-}$. This means that in the absence of adequate ventilation, as simulated in our ex vivo model through elevated $\mathrm{CO}_{2}$ supply without additional oxygenation, ADVOS multi could "imitate" the renal compensatory mechanism for acidemia control [26].

$$
\mathrm{H}_{2} \mathrm{CO}_{3} \leftrightarrow \mathrm{CO}_{2}+\mathrm{H}_{2} \mathrm{O} \leftrightarrow \mathrm{HCO}_{3}^{-}+\mathrm{H}^{+}
$$

In the case of ADVOS, the higher the dialysate $\mathrm{pH}$ setting, the higher the $\mathrm{H}^{+}$concentration reduction is achieved (Fig. 2). This results into $\mathrm{HCO}_{3}{ }^{-}$generation, which helps to correct $\mathrm{HCO}_{3}{ }^{-}$levels during metabolic acidosis (Fig. 5). This is only possible if a concomitant $\mathrm{pCO}_{2}$ reduction is achieved, which does not occur during conventional renal replacement therapy or bicarbonate infusion. In fact, in the absence of adequate ventilation (i.e., $\mathrm{CO}_{2}$ removal), a metabolic acidosis can turn into a hypercapnic acidosis (Fig. 5), which cannot be corrected with conventional CVVHD (Fig. 4). 
The Stewart model to explain acid-base balance with the ADVOS system

We analyzed if the observed changes could also be explained by the mathematical model proposed by Stewart [20] and its revision by others [27-29], who showed that three independent variables are responsible for determining the $\mathrm{pH}$ in plasma: $\mathrm{PaCO}_{2}$, plasma weak acids (i.e., phosphate and albumin), and the SID as the difference between fully dissociated plasma anions and cations. Therefore, neither the $\mathrm{H}^{+}$ movement nor the buffering effect of $\mathrm{HCO}_{3}{ }^{-}$is necessary or sufficient to explain acid-base regulation. In any case, our data can be also explained using this model, as shown in Additional files.

Taking into account the conclusions obtained by Constable [21], blood pH could be predicted solely by changes in total protein, $\mathrm{pCO}_{2}$, and SID. Applying this to our data demonstrated a perfect correlation between the measured and the calculated $\mathrm{pH}$ in the outlet of the dialyzer (Additional file 2: Figures S1 and S2; Additional file 3: Figures S3 and S4; Additional file 4: Figures S5 and S6). Indeed, SID variations were correlated with dialysate $\mathrm{pH}$ variations, specifically at high values of 10.0. To reach such a dialysate $\mathrm{pH}$, a higher rate of basic/acidic concentrate is needed, which provides higher $\mathrm{Na}^{+}$ and lower $\mathrm{Cl}^{-}$, and can therefore result into SID reductions in blood through the dialyzer. Moreover, the presence of albumin as a weak acid facilitates this process.

Although SID and $\mathrm{pCO}_{2}$ are considered independent variables by Stewart, it has been suggested that an interdependency between both values might exist [30]. Langer et al. observed that the greater the variation in $\mathrm{pCO}_{2}$, the greater the reduction in plasma SID. We might reach the same conclusion when, as this group did, quartiles of $\mathrm{pCO}_{2}$ variations are analyzed and plotted against the corresponding SID variations $\left(r^{2}=0.991\right.$; Additional file 6: Figure S8). However, if raw data are drawn, no correlation is observed $\left(r^{2}=0.190\right.$; Additional file 7: Figure S9).

\section{Rationale for multi organ support with ADVOS during acidosis}

Using either the classical or the modern approach, this work should serve as a proof of concept of the ability of the ADVOS therapy to correct acid-base disturbances. As described above, the lungs (i.e., $\mathrm{CO}_{2}$ ) and kidneys (i.e., $\mathrm{NH}_{4}{ }^{+}, \mathrm{HCO}_{3}{ }^{-}$, for the classic approach or $\mathrm{Na}^{+}, \mathrm{Cl}^{-}$for the Stewart model) are usually defined to be responsible for acid-base control. However, the liver plays also an important role (i.e., metabolism of organic acid anions like citrate and certain amino acids) [31, 32] and can also be supported by ADVOS. Indeed, acidemia and metabolic acidosis are associated with poor outcome in cirrhosis patients, as demonstrated by Drolz and colleagues in a cohort of 178 critically ill patients with liver cirrhosis and acute on chronic liver failure [33].Therefore, attention should not only be paid to a specific organ. In addition, the majority of the cases of acidosis reflect a mixed nature, involving both a metabolic and a respiratory component [2]. In view of this, a multiple organ approach seems to be needed while facing acidosis, where the variety of adjustable parameters of the ADVOS multi might play an important role.

\section{Limitations and justification of the ex vivo model}

Although our results are encouraging, our work is limited by its in vitro nature, the selection of parameters, and the number of experiments performed. Nevertheless, so as 
to serve as a proof of concept, this experimental setting is adequate based on the following: (1) the different parameters analyzed and varied (i.e., $\mathrm{pCO}_{2}, \mathrm{HCO}_{3}{ }^{-}$, lactate) to resemble different types of acidosis, (2) the possibility to control the concrete amount of acid load (i.e., $\mathrm{CO}_{2}$ and/or lactic acid) being supplied, and (3) the analysis of inlet and outlet measurements to describe the course of blood values along the dialyzer. These encouraging results need now to be confirmed in the clinical setting.

\section{Conclusions}

In conclusion, the ADVOS albumin hemodialysis system was able to remove $61 \mathrm{ml} / \mathrm{min}$ while maintaining blood gas values in the physiological range or up to $142 \mathrm{ml} / \mathrm{min} \mathrm{CO}_{2}$ in hypercapnic conditions at low blood flow without the need of a gas phase. Blood pH was maintained stable within the physiological range of $7.35-7.45$ by the albumin-containing dialysate. Moreover, during continuous lactic acid addition, up to $3 \mathrm{mmol} / \mathrm{min}$ of acid load was compensated. The major determinants to stabilize blood $\mathrm{pH}$ were blood flow, dialysate composition, and blood bicarbonate levels. The mechanism of action of ADVOS multi can be explained using either the classical acid-base balance model or the newer Stewart approach. This feature in combination with the previously demonstrated ability to eliminate water-soluble and protein-bound toxins may be of valuable help in the management of critically ill patients with multiple organ failure.

\section{Supplementary information}

Additional file 1: Table S1. Results from blood gas analysis obtained after hemodialysis of swine blood under different treatment settings with ADVOS and different CO2 supply during experimental Set 1. Samples were taken in the inlet and outlet of the dialyzer at the same time. Mean \pm S.D. Table S2. Results from blood gas analysis obtained after hemodialysis of swine blood under different treatment settings with ADVOS and different lactic acid supply during experimental Set 2 . Samples were taken in the inlet and outlet of the dialyzer at the same time. Mean \pm S.D.

Additional file 2: Figure S1 and S2. Correlation between variations of inlet and outlet $\mathrm{pCO}_{2}$ with measured or calculated variations in blood pH during experimental Set 1 and Set 2, respectively. The black line shows values obtained from BGA. The green line shows values calculated according to the Equation 2 (see methods 2.7), According to these data, the removal of $\mathrm{CO}_{2}$ and the corresponding decrease on $\mathrm{pCO}_{2}$ accounts for the elevation of blood $\mathrm{pH}$. The higher the $\mathrm{CO}_{2}$ removal, the higher the $\mathrm{pH}$ increase in blood that can be achieved.

Additional file 3: Figure S3 and S4. Representation of all the BGA tests performed during the experiments from Set 1 and Set 2, respectively. The black line shows values obtained from blood. The green line shows calculated values considering variations (inlet - outlet) from $\mathrm{pCO}_{2}$ and $\mathrm{SID}$ according Equation 2 (see methods 2.7). It is assumed that no variation on total protein content occurs as it cannot be lost in the dialyzer. Therefore, variations in $\left[A_{t o t}\right]$ are not considered within the equation. These results show, that taking into account variations in pCO2 and SID along the dialyzer, the resulting $\mathrm{pH}$ at the outlet can be predicted following the calculations suggested by Stewart [29].

Additional file 4: Figure S5 and S6. Correlation of the measured and calculated $\mathrm{pH}$ variations between the inlet and the outlet of the dialyzer $\left(\Delta \mathrm{pH}=\mathrm{pH}_{\text {outlet }}-\mathrm{pH}_{\text {inlet }}\right)$ during experimental Set 1 and 2, respectively. Measured values were obtained from BGA while calculated values were obtained according to the Equation 2 . Each line accounts for a combination of different ADVOS settings (blood flow/concentrate flow). As demonstrated for Supplementary Figure 3 and 4, for each of the settings, there is a correlation between measured and calculated values according to the Stewart approach.

Additional file 5: Figure S7. Buffer capacity of a dialysate containing $20 \mathrm{mmol} / \mathrm{l}$ sodium bicarbonate with or without albumin $(2 \mathrm{~g} / \mathrm{dl})$. The buffer capacity $(\beta)$ is defined as the moles of an acid or base necessary to change the $\mathrm{pH}$ of a solution by 1 , divided by the $\mathrm{pH}$ change and the volume of buffer in liters.

Additional file 6: Figure S8. Analysis of SID variations (outlet - inlet) according to quartiles of $\mathrm{pCO}_{2}$ variation (outlet - inlet). As shown in [30]. Mean \pm S.D.

Additional file 7: Figure S9. Correlation between SID variations (outlet - inlet) and $\mathrm{pCO}_{2}$ variation (outlet - inlet) using raw data. These data show, that in our experiments there is no interdependence between $\mathrm{SID}$ and $\mathrm{pCO}_{2}$ variation, contrary to what is described in [30]. Using quartiles for $\mathrm{pCO}_{2}$ variation as shown in Supp. Figure 8, an artefactual correlation might be created. 


\begin{abstract}
Abbreviations
ADVOS: ADVanced Organ Support; AKI: Acute kidney injury; ARDS: Acute respiratory distress syndrome; $\mathrm{CO}_{2}$ : Carbon dioxide; COPD: Chronic obstructive pulmonary disease; $\mathrm{HCO}_{3}$ : Bicarbonate; ICU: Intensive care unit; MOF: Multiple organ failure; MOST: Multiple organ support therapy; $\mathrm{Na}_{2} \mathrm{CO}_{3}$ : Sodium carbonate; $\mathrm{NaHCO}_{3}$ : Sodium bicarbonate; $\mathrm{PaCO}_{2}$ : Arterial partial pressure of carbon dioxide; $\mathrm{pCO}_{2}$ : Partial pressure of carbon dioxide; $\mathrm{Q}_{\mathrm{b}}$ : Blood flow; $\mathrm{Q}_{\mathrm{c}}$ : Concentrate flow; SD: Standard deviation; SID: Strong ion difference; SOFA: Sepsis-related organ failure assessment; SOP: Standard operating procedure; $\mathrm{TCO}_{2}$ : Total content of $\mathrm{CO}_{2}$
\end{abstract}

\title{
Acknowledgements
}

Not applicable

\section{Authors' contributions}

AP contributed to the study design; performed the experiments, data acquisition, and statistical analysis; and wrote the manuscript. JK contributed to the critical review with important intellectual input. JH performed the experiments, data acquisition, and statistical analysis. BK contributed to the study design, writing of the manuscript, and critical review with important intellectual input. All authors are accountable for all aspects of the work, and all authors read and approved the final manuscript.

\section{Funding}

Funding information is not applicable.

\section{Availability of data and materials}

The datasets used and/or analyzed during the current study are available from the corresponding author on reasonable request.

\section{Ethics approval and consent to participate}

Not applicable

\section{Consent for publication}

Not applicable

\section{Competing interests}

BK is the Chief Executive Officer (CEO) of the company ADVITOS GmbH and owns stocks in the company. AP is employed by ADVITOS GmbH. JK has a consulting arrangement with ADVITOS GmbH. The other authors declare that they have no competing interests.

\section{Author details}

${ }^{1}$ ADVITOS GmbH, Agnes-Pockels-Bogen 1, 80992 Munich, Germany. ${ }^{2}$ Center for Critical Care Nephrology, Department of Critical Care Medicine, University of Pittsburgh Medical Center, Pittsburgh, USA. ${ }^{3}$ Faculty of Medicine,

Ludwig-Maximilians-Universität München, Munich, Germany.

Received: 5 July 2019 Accepted: 9 September 2019

Published online: 18 September 2019

\section{References}

1. Tiruvoipati R, Pilcher D, Buscher H, Botha J, Bailey M (2017) Effects of hypercapnia and hypercapnic acidosis on hospital mortality in mechanically ventilated patients. Crit Care Med. 45:e649-e656. https://doi.org/10.1097/CCM. 0000000000002332

2. Jung B, Rimmele T, Le Goff C, Chanques G, Corne P, Jonquet O et al (2011) Severe metabolic or mixed acidemia on intensive care unit admission: incidence, prognosis and administration of buffer therapy. A prospective, multiple-center study. Crit Care. 15:R238. https://doi.org/10.1186/cc10487

3. Kim HJ, Son YK, An WS (2013) Effect of sodium bicarbonate administration on mortality in patients with lactic acidosis: a retrospective analysis. PLoS One. 8:e65283. https://doi.org/10.1371/journal.pone.0065283

4. Kluge S, de HG, Jarczak D, Nierhaus A, Fuhrmann V (2018) Lactic acidosis - update 2018. Dtsch Med Wochenschr. 143: 1082-1085. https://doi.org/10.1055/a-0585-7986

5. Critical care nephrology: Springer; 1998.

6. Kellum JA, Song M, Li J (2004) Science review: Extracellular acidosis and the immune response: clinical and physiologic implications. Crit Care. 8:331-336. https://doi.org/10.1186/cc2900

7. Zampieri FG, Kellum JA, Park M, Ranzani OT, Barbeiro HV, de SHP et al (2014) Relationship between acid-base status and inflammation in the critically ill. Crit Care. 18:R154. https://doi.org/10.1186/cc13993

8. Lardner A (2001) The effects of extracellular pH on immune function. J Leukoc Biol. 69:522-530

9. Mitchell JH, Wildenthal K, Johnson RL (1972) JR. The effects of acid-base disturbances on cardiovascular and pulmonary function. Kidney Int. 1:375-389

10. Stringer W, Wasserman K, Casaburi R, Porszasz J, Maehara K, French W (1994) Lactic acidosis as a facilitator of oxyhemoglobin dissociation during exercise. J Appl Physiol (1985). 76:1462-1467. https://doi.org/10.1152/jappl. 1994.76.4.1462

11. Lejeune P, Brimioulle S, Leeman M, Hallemans R, Melot C, Naeije R (1990) Enhancement of hypoxic pulmonary vasoconstriction by metabolic acidosis in dogs. Anesthesiology. 73:256-264

12. Farber MO, Szwed JJ, Dowell AR, Strawbridge RA (1976) The acute effects of respiratory and metabolic acidosis on renal function in the dog. Clin Sci Mol Med. 50:165-169 
13. Tournadre JP, Allaouchiche B, Malbert CH, Chassard D (2000) Metabolic acidosis and respiratory acidosis impair gastropyloric motility in anesthetized pigs. Anesth Analg. 90:74-79

14. Engstrom M, Schott U, Romner B, Reinstrup P (2006) Acidosis impairs the coagulation: a thromboelastographic study. J Trauma. 61:624-628. https://doi.org/10.1097/01.ta.0000226739.30655.75

15. Al-Chalabi A, Matevossian E, V Thaden A-K, Luppa P, Neiss A, Schuster T et al (2013) Evaluation of the Hepa Wash(R) treatment in pigs with acute liver failure. BMC Gastroenterol. 13:83. https://doi.org/10.1186/1471-230X-13-83

16. Al-Chalabi A, Matevossian E, von Thaden A, Schreiber C, Radermacher P, Huber W et al (2017) Evaluation of an ADVanced Organ Support (ADVOS) system in a two-hit porcine model of liver failure plus endotoxemia. Intensive Care Med Exp. 5:31. https://doi.org/10.1186/s40635-017-0144-3

17. Huber W, Henschel B, Schmid R, Al-Chalabi A (2017) First clinical experience in 14 patients treated with ADVOS: a study on feasibility, safety and efficacy of a new type of albumin dialysis. BMC Gastroenterol. 17:32. https://doi.org/10.1186/ s12876-017-0569-x

18. Fuhrmann VH, Jarczak D, Boenisch O, Kluge S (2018) ADVOS reduces liver and kidney disease markers and corrects acidosis: the Hamburg experience. Critical Care. 22:82

19. May AG, Sen A, Cove ME, Kellum JA, Federspiel WJ (2017) Extracorporeal CO2 removal by hemodialysis: in vitro model and feasibility. Intensive Care Med Exp. 5:20. https://doi.org/10.1186/s40635-017-0132-7

20. Stewart PA (1983) Modern quantitative acid-base chemistry. Can J Physiol Pharmacol. 61:1444-1461

21. Constable PD (2001) Total weak acid concentration and effective dissociation constant of nonvolatile buffers in human plasma. J Appl Physiol (1985). 91:1364-1371. https://doi.org/10.1152/jappl.2001.91.3.1364

22. Kaneko K, Chuang VTG, Minomo A, Yamasaki K, Bhagavan NV, Maruyama T, Otagiri M (2011) Histidine146 of human serum albumin plays a prominent role at the interface of subdomains IA and IIA in allosteric ligand binding. IUBMB Life. 63:277-285. https://doi.org/10.1002/iub.457

23. Abe $\mathrm{H}$ (2000) Role of histidine-related compounds as intracellular proton buffering constituents in vertebrate muscle. Biochemistry (Mosc). 65:757-765

24. Szebedinszky C, Gilmour KM (2002) The buffering power of plasma in brown bullhead (Ameiurus nebulosus). Comp Biochem Physiol B Biochem Mol Biol. 131:171-183

25. Skelton LA, Boron WF, Zhou Y. Acid-base transport by the renal proximal tubule. J Nephrol. 2010;23 Suppl 16:S4-18.

26. Dorman PJ, Sullivan WJ, Pitts RF (1954) The renal response to acute respiratory acidosis. J Clin Invest. 33:82-90. https:// doi.org/10.1172/JCl102874

27. Figge J, Mydosh T, Fencl V (1992) Serum proteins and acid-base equilibria: a follow-up. J Lab Clin Med. 120:713-719

28. Figge J, Rossing TH, Fencl V (1991) The role of serum proteins in acid-base equilibria. J Lab Clin Med. 117:453-467

29. Kellum JA (2009) In: Paul WG, WG EP (eds) Stewart's textbook of acid-base, 2nd edn. United States of America, Lulu.com

30. Langer T, Scotti E, Carlesso E, Protti A, Zani L, Chierichetti M et al (2015) Electrolyte shifts across the artificial lung in patients on extracorporeal membrane oxygenation: Interdependence between partial pressure of carbon dioxide and strong ion difference. J Crit Care. 30:2-6. https://doi.org/10.1016/j.jcrc.2014.09.013

31. Scheiner B, Lindner G, Reiberger T, Schneeweiss B, Trauner M, Zauner C, Funk G-C (2017) Acid-base disorders in liver disease. J Hepatol. 67:1062-1073. https://doi.org/10.1016/j.hep.2017.06.023

32. Gullo A, Häussinger D (1998) The role of the liver in acid-base regulation: anaesthesia, pain, intensive care and emergency medicine - A. Springer Milan, P.I.C.E

33. Drolz A, Horvatits T, Roedl K, Rutter K, Brunner R, Zauner C et al (2018) Acid-base status and its clinical implications in critically ill patients with cirrhosis, acute-on-chronic liver failure and without liver disease. Ann Intensive Care. 8:48. https:/doi.org/10.1186/s13613-018-0391-9

\section{Publisher's Note}

Springer Nature remains neutral with regard to jurisdictional claims in published maps and institutional affiliations.

\section{Submit your manuscript to a SpringerOpen ${ }^{\circ}$ journal and benefit from:}

- Convenient online submission

- Rigorous peer review

- Open access: articles freely available online

High visibility within the field

- Retaining the copyright to your article

Submit your next manuscript at $\boldsymbol{s p r i n g e r o p e n . c o m ~}$ 